\title{
Performance and Mechanism of the in-situ
}

Restoration Effect on VHCs in the Polluted River

Water Based on the Orthogonal Experiment:

Photosynthetic Fluorescence Characteristics and Microbial Community Analysis.

Jia Wang

China University of Geosciences Beijing

Shuangrong Wu

Tangshan University

Qi Yang

China University of Geosciences Beijing

Yonggang Gu ( $\nabla$ xs1547398@163.com )

Beijing Institute of Water Sceince and Technology

\section{Peijing Wang}

Beijing Institute of Water Scinence and Technology

Zhaoxin Li

Beijing Institute of Water Science and Technology

Lei Li

Beijing Institute of Water Science and Technology

\section{Research Article}

Keywords: Volatile halogenated hydrocarbons, Orthogonal tests, in-situ ecological restoration, Microbial community

Posted Date: October 22nd, 2021

DOl: https://doi.org/10.21203/rs.3.rs-904503/v1

License: (c) (1) This work is licensed under a Creative Commons Attribution 4.0 International License. Read Full License 
18845-4. 
1 Performance and mechanism of the in-situ restoration effect on VHCs in the polluted river 2 water based on the orthogonal experiment: photosynthetic fluorescence characteristics and microbial community analysis.

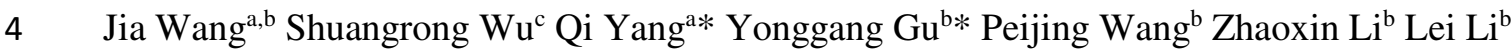
5 a School of Water Resources and Environment, China University of Geosciences (Beijing), Beijing 100083, China,

${ }^{\mathrm{b} B e i j i n g}$ Institute of Water Science and Technology, Beijing 100048, China,

$8 \quad{ }^{\mathrm{c} C o l l e g e}$ of Civil and Architectural Engineering, Tangshan University, Tangshan 063009, 9 China 


\section{Abstract:}

Volatile halogenated hydrocarbons (VHCs) attracted many attentions due to its toxic and persistent in the environment. In this research, a novel in situ ecological restoration reactor was applied to the degradation of VHCs in polluted river water. The optimized working condition adaptation of the in-situ restoration technique was evaluated through orthogonal tests. The experiments showed that when the water depth was $0.4 \mathrm{~m}$, the HRT was $5 \mathrm{~d}$ and the current velocity was $1 \mathrm{~m} / \mathrm{s}$, VHCs removal efficiencies could achieve favorable value. The $\mathrm{CHCl}_{3} \mathrm{CCl}_{4}, \mathrm{C}_{2} \mathrm{HCl}_{3}$ and $\mathrm{C}_{2} \mathrm{Cl}_{4}$ removal efficiency could reach $70.27 \%, 70.59 \% 67.74 \%$ and $81.82 \%$, respectively. F test results showed that both HRT and water depth were significantly related to the removal efficiency of reactor. Besides, using underwater modulated chlorophyll fluorometer analyzed the rapid light curves (RLC) of plants in the experiment, which showed that the VHCs of damaged river was harmful to the physiological state of the plants. Moreover, the microbial community structures of fillers in the reactor were tested by highthroughput sequencing, the findings supported that the microbial community made a great response to adapt to the changes of environment of the reactor. The relative abundance of Rhodocyclaceae increased slightly, which hinted that it had good adaptability to VHCs in polluted river water. The research results confirmed that in situ ecological restoration reactor was an economical technology for removal VHCs in polluted river water.

Key words: Volatile halogenated hydrocarbons; Orthogonal tests; in-situ ecological restoration; Microbial community 


\section{Introduction}

Urbanization in China has accelerated the transformation of geomorphological features and ecological environment in urban river, which contained the decrease on the hydrological connectivity and the pollutants accumulated at the bottom of the river channels (Wang et al., 2017). With the process of urbanization continues to move forward, the destruction intensified of urban water environment, especially in urban rivers and lakes environment (Lu et al., 2018). Human activity changes the original shape of the river, injects additional pollutants to affect the water quality frequently (Hirsch et al., 2010). Volatile halogenated hydrocarbons (VHCs) were constituted with a series of diversified organic compounds, most of which with the characteristics of environmental persistence, bioaccumulation and biology toxicity (Zou et al., 2006; Song et al., 2017). Meanwhile, some VHCs instant vaporized into air environment as a consequence of low boiling points, adding air pollutant and the local people risk of illness in urban area (Mun \& Townley, 2021). VHCs has been widely accepted as a major source of photochemical smog since the beginning of the 21th century. Besides, variety of VHCs produced by plastics petroleum and landfill leachate influx into urban river alteration the characteristics of water environment and initiation potential adverse effects on human (Wang et al., 2020). VHCs would cause continuous hazard in environmental media, which was the particularly sensitive and prominent in river within the city limits.

River pollution caused by human activities is very common in world, many regions and countries begin to show concerns for the river quality and take measures to treat it. As we all know, many factors such as the water depth and current velocity, regulate actual situation of the river and affect pollutant distribution in the damaged river (Jiang et al., 2017; Rugner et al., 
2019). Due to the complexity characteristics of river pollution, the traditional water treatment process is difficult for practical application (Giripunje et al., 2015).

Actually, both phytoremediation and slope wetland system are known as green and efficient in situ water environment remediation treatments, which could alter water quality and flow regime to a certain extent (Ladislas et al., 2011). Submerged macrophytes as a representative eco-engineering plants, it also is an important component of river ecosystem, which have capable of influencing various biotic and abiotic environments, including the status of the rivers (Zhang et al., 2018; Özgencil et al., 2020). Slope wetland system has characterized by good geomorphology adaptability and flexible controllability, which was suitable for recovery and remediation of damaged river (Wang et al., 2021). Aimed at maintenance and restoration polluted river water, the two technologies need to be suitable combination with low cost and simple management mode (Nilsson et al., 2015). The combination of the two methods can not only expand the suitable construct methods to the riverway physiognomy, but also improve the removal efficiency on the organic matters in the polluted river water. Additionally, both Submerged macrophytes and slope wetland are biological systems involved in the degradation of organic matter. And the plants in conjunction with microflora in the system, which would play cleaning function on the coupling system by the bioremediation function (Wang et al., 2017). Hence, the regulation on plant physiological activities and microbial community status was a vital concern, which involve in optimized the pollutant removal and performance on coupling system.

Water pollution prevention action plan has been applied to numerous black-stinking water bodies in China, which met the requirements on elimination eutrophication and promote 
water resources management (Song et al., 2017). Many rivers restoration projects have been applied to urban river remediation through the last few years, but the degradation VHCs in polluted river water have been rarely reported. In view of VHCs are toxic and persistent in the environment, determining its content of polluted river water and proposed appropriate measures to restore the river ecosystem is essential measures to local population health.

In view of the above aspects, in situ restoration reactor was used as the research carrier, and the purification effect on VHCs in the polluted river water was investigated. After due consideration, different experimental factors were set on orthogonal the outdoor simulation experiment to determine the optimal conditions on the reactor. The underwater modulation chlorophyll fluorescence was employed to analyze the physiological state of plants at the insitu restoration reactor at the same. In addition, the headspace gas chromatography was used as detected the content of VHCs in damaged river and tested the VHCs variation on polluted river water under the system treatment. Besides, the change of substrate microorganism was measured before and after the experiment to evaluate the flora on the dichlorination reaction. The aim of this research was to explore and optimize the actual operation requirement of the in-situ restoration reactor through microbial resource management and some relevant analysis instruments. And the impact on experimental factors were evaluated and pollutant decomposition mechanism in the reactor were comprehensively analyzed.

\section{Materials and methods}

\subsection{Experimental device}

To assure an effective and authenticity research, the experiment was carried out outdoors. One device was set up in the experiment, which dimension was $1 \mathrm{~m}$ high, $2 \mathrm{~m}$ wide and $7 \mathrm{~m}$ 
long. The experimental devices were consisted of water inlet pipe, water outlet, water tank and sampling ports. In the flank of all reactors, three wastewater sampling pipes are arranged in three rows with the height of $0.4 \mathrm{~m}, 0.6 \mathrm{~m}$ and $0.8 \mathrm{~m}$ (to the bottom). Slope wetland contained three plants (ScirpusvalidusVahl, Typha orientalis Presl and Lythrum salicaria L.), which was planted from bottle to up, respectively. And planting density was set at 30clumps $/ \mathrm{m}^{2}$. Potamogeton wrightii Morong and Potamogeton pectinatus was closely adjacent seeded around the ScirpusvalidusVahl in the sediment of the reactor, and the planting density was set at 30clumps $/ \mathrm{m}^{2}$. The pushing flow device (QJB0.85) was purchased from Sapphire environmental protection (Nanjing, China), and impeller diameter was $220 \mathrm{~mm}$. In order to guarantee the replenishment and drain of the reactor steadily, the polluted river water employed in the reactor was supplied through the water tank. In addition, the polluted river water directly extracted from the damaged river by the water pump, which enhance the reliability of the simulation experiment and guarantee the authenticity of the results to a certain extent. The experimental reactor is shown in Fig.1.

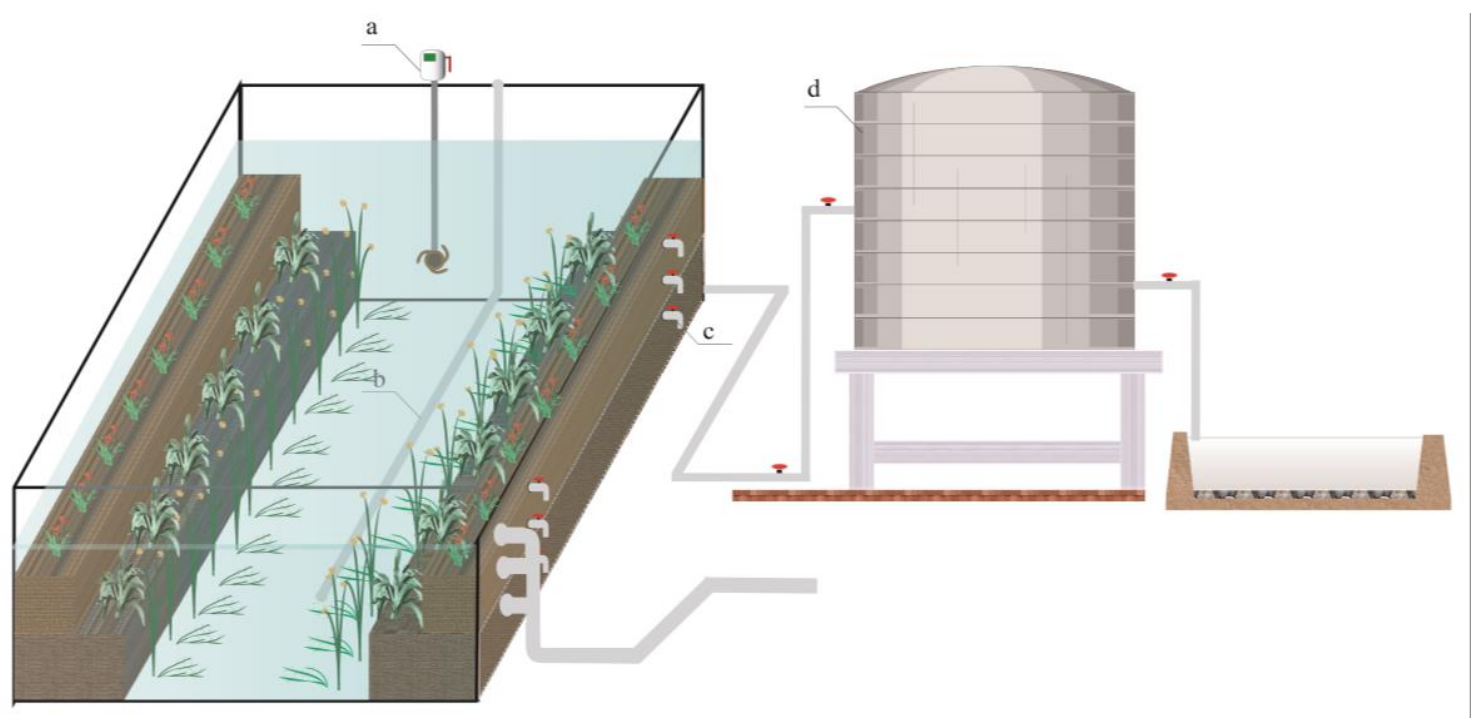

Fig.1 Experimental reactor (a. plug flow device b. water replenishing pipe c. sampling ports d. water tank) 


\subsection{Experimental chemical and instrument}

The chemicals obtained methanol and ethanol, which was used in the experiment were of guaranteed reagent (GR) and purchased from Beijing chemical plant (Beihua, China). Standard solutions (GSB07-1982-2005) of 1,000 $\mu \mathrm{g} \cdot \mathrm{mL}^{-1}$ VHCs in ethanol were purchased from standard sample Institute of Ministry of environmental protection, including $\mathrm{CHCl}_{3}$, $\mathrm{CCl}_{4}, \mathrm{C}_{2} \mathrm{HCl}_{3}$ and $\mathrm{C}_{2} \mathrm{Cl}_{4}$. Analytical grade of $\mathrm{NaCl}$ were purchased from Yongda Chemical Reagent Co., Ltd (Tianjin, China). Headspace bottle and micropipettor (1 $\mu \mathrm{L}, 10 \mu \mathrm{L}, 50 \mu \mathrm{L})$ were purchased from high pigeon instrument (Shanghai, China). $1,000 \mu \mathrm{g} \cdot \mathrm{mL}^{-1}$ chloride standard solutions (GSB 07-1267-2000) was purchased from the resources platform of the national standard material. Main instruments of the experiment contained: headspace sampler (7697A, Aglient, America), headspace gas chromatograph (7890A, Aglient, America), capillary chromatographic column (HP-5MS, Aglient, America), ultra-pure water machine (CM-R0-C2, Anshi, China), underwater modulated chlorophyll fluorometer (DIVING-PAMII, Zealqueit, China) and associated accessories.

\subsection{Gas chromatography operating conditions}

HS-GC analysis conducted with the environmental protection standards of HJ620-2011. The micropipette was used as transfer standard solutions of VHCs, which was diluted by methanol to obtain the $10 \mu \mathrm{g} \cdot \mathrm{mL}^{-1}$ preparation solutions. Preparation solutions was allowed the headspace extraction and gas phase operations relatively handy. The $\mathrm{NaCl}$ was dried to a constant weight $\left(350^{\circ} \mathrm{C}\right.$ for $\left.3 \mathrm{~h}\right)$ and then cooled at room temperature, which was added into headspace bottle followed immediately when it has cooled. At the same time, 5, 10, 20, 30, $50 \mu \mathrm{L}$ preparation solutions was added up respectively into $10 \mathrm{~mL}$ ultra-pure water in the 
141

headspace bottle, and the mixture sufficient agitated respectively. After the above operations, the standard solution was obtained. HS-GC operations were composed of headspace injection, high temperature separation and analyte display. A robotic arm and a headspace generation unit was consisted the 111-space autosampler, which could heat samples and convey the bottles into the GC equipment. Chromatographic conditions: Initial temperature was $40^{\circ} \mathrm{C}$ for $2 \mathrm{~min}$ and increased to $100^{\circ} \mathrm{C}$ at $60{ }^{\circ} \mathrm{C} \min ^{-1}$, then $100{ }^{\circ} \mathrm{C}$ to $200{ }^{\circ} \mathrm{C}$ at $10{ }^{\circ} \mathrm{C} \min ^{-1}$. Detection temperature was set as $320{ }^{\circ} \mathrm{C}$. Helium used as carrier gas and flow velocity was $1.0 \mathrm{~mL} \cdot \mathrm{min}^{-1}$. The results were shown in the Fig.2a).

The signal was gathered from GC equipment, which reflected the characteristic on analytes by the position and size of peak area. The external standard method was used to establish standard line, the results were shown in the Fig.2b).
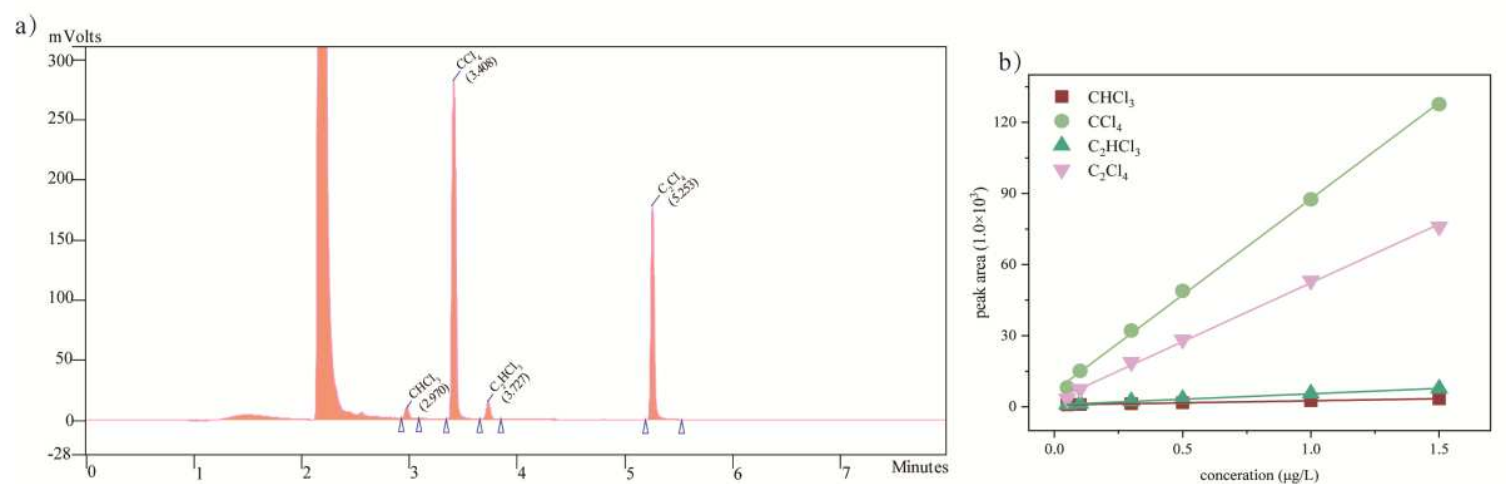

Fig.2 Gas chromatogram analysis of target compounds (a. Gas chromatogram of VHCs b. Standard line of VHCs)

\subsection{Experimental site and influent quality}

In this study, the Xiaozhong river in Tongzhou District of Beijing was selected as experimental site. The average annual atmospheric temperature of Tongzhou District is 13$24^{\circ} \mathrm{C}$. The river runs through an urban area and it adopts the way of reclaimed water 
replenishment, and the main stream is set with several sewage outlets, the self-purification capacity of water body is poor. The experimental site is located in Tongzhou Xiaozhong River experimental base $\left(116^{\circ} 67^{\prime} \mathrm{E}, 39^{\circ} 93^{\prime} \mathrm{N}\right)$, and the sampling point is located at the confluence point of five rivers. Its variation can effectively reflect the interaction between upstream and downstream water quality. The experimental site is shown in Fig.3.

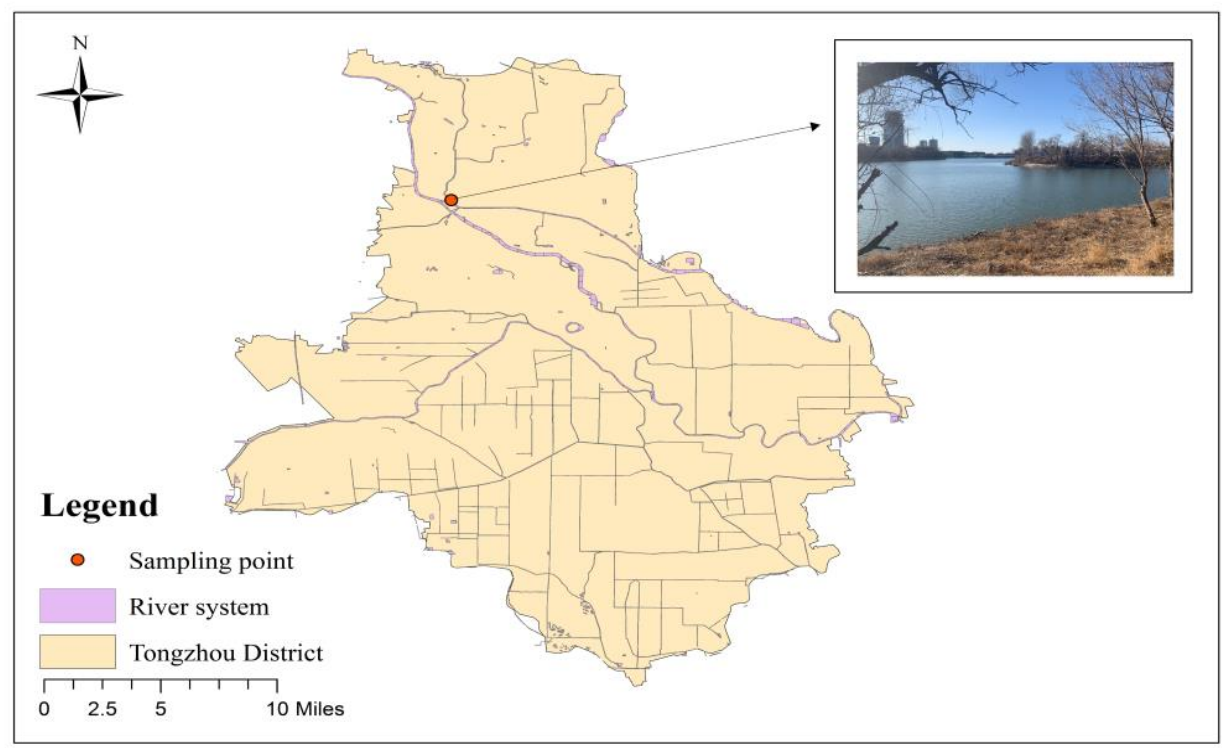

Fig.3 Experimental site

The Xiaozhong river receives multiplex sewage throughout the year, the pollutants mainly come from the surrounding domestic garbage, sewage treatment plants and rainfall, which aggravated river channel damaged situation (Zhang et al., 2020a). The integral state of river was sluggish, and some area existed stagnant zone. Using the $1000 \mathrm{~mL}$ sample bottle, water samples were directly collected from the experimental site and were analyzed in the laboratory (sampling two times). The characteristics of polluted river water are shown in Tab. 1

Table 1Characteristics of polluted river water 


\begin{tabular}{cccccc}
\hline Parameter & $\begin{array}{c}\mathrm{CHCl}_{3}(\mu \\
\left.\mathrm{g} \cdot \mathrm{L}^{-1}\right)\end{array}$ & $\begin{array}{c}\mathrm{CCl}_{4}(\mu \mathrm{g} \cdot \mathrm{L} \\
\left.{ }^{-1}\right)\end{array}$ & $\begin{array}{c}\mathrm{C}_{2} \mathrm{HCl}_{3}(\mu \mathrm{g} \cdot \mathrm{L} \\
\left.{ }^{-1}\right)\end{array}$ & $\begin{array}{c}\mathrm{C}_{2} \mathrm{Cl}_{4}\left(\mu \mathrm{g} \cdot \mathrm{L}^{-}\right. \\
\left.{ }^{1}\right)\end{array}$ & $\mathrm{pH}$ \\
\hline Content & 0.21 & 0.17 & 0.37 & 0.11 & $5.9 \sim 7.1$ \\
\hline
\end{tabular}

174

175

176

177

\subsection{Experimental methods}

In this study, in-situ restoration effect on polluted river water were evaluated by orthogonal tests under the water depth, HRT and current velocity as variables. In order to simulate the influence on river flow, considering the characteristics of wetlands at the same, the variation on HRT was applied to the reactor to meet the requirements. The HRT was calculated by the Eq.1. The three factors were selected as influencing factors, containing $\operatorname{HRT}(1,3$, and $5 \mathrm{~d})$, current velocity $(1,2$, and $3 \mathrm{~m} / \mathrm{s})$ and water depth(0.4, 0.6, and $0.8 \mathrm{~m})$ and three levels were taken for each factor. And the fictitious factors were added to the orthogonal matrix, for avoiding the influence of error caused by stochastic factors.

$$
H R T=\frac{V}{Q}
$$

$V$-The treatment volume in reactor $\left(\mathrm{m}^{3}\right)$

$Q$ - The influent flow in reactor $\left(\mathrm{m}^{3} / \mathrm{d}\right)$

Meanwhile, the methods of outdoor simulation experiment were adopted to the experiment to assure the factuality of results. DNA was extracted from the soil and filler samples with a FastDNA skin for soil Isolation kit (116560200, MP, America) on the basis of product description. The extracted DNA was stored at $-20^{\circ} \mathrm{C}$ and follow operation contain amplification, enrich and construct the template of miseq library was finished by Beijing Allwegene Tech and Monitoring Technology Co., Ltd.. The microbial community analysis of the experiment was completed by illuminamiseq pe300 sequencing platform. Water samples were collected in glass sampling bottle $(50 \mathrm{~mL})$ and stored at $4{ }^{\circ} \mathrm{C}$ until detect. The samples 
before and after treatment conveyed by using headspace sampler (HS) and the content of

VHCs in water samples was measured by headspace gas chromatograph (GC) with the help of capillary chromatographic column. Plants physiological status were analyzed by underwater modulated chlorophyll fluorometer.

\section{Results and discussion}

\subsection{The degradation on VHCs under orthogonal experiment}

\subsubsection{Construction of orthogonal experiment}

Transport of pollutants in the damaged river are closely associated with hydrodynamics situation on the polluted river water, which included current velocity, river flow, water depth and the like (Anwar Sadat et al., 2020). L $_{9}\left(3^{4}\right)$ orthogonal experiment was applied in this study.

Details of the factors and levels in orthogonal experiment is shown in Tab. 2.

Table 2 Factors and levels in the orthogonal experiment

\begin{tabular}{cccc}
\hline Factors & \multicolumn{3}{c}{ Level } \\
\cline { 2 - 4 } & 1 & 2 & 3 \\
\hline Water depth $(\mathrm{m})$ & 0.4 & 0.6 & 0.8 \\
HRT $(\mathrm{d})$ & 1 & 3 & 5 \\
Current velocity $(\mathrm{m} / \mathrm{s})$ & 1 & 2 & 3 \\
Fictitious factors & 1 & 2 & 3 \\
\hline
\end{tabular}

\subsubsection{Orthogonal experiment results}

Aiming to experimental materials decrement, orthogonal experiments were constructed on representative points with mutual independence, which could validate the experimental result under various factors and obtained the optimization designation (Wang et al., 2019). The removal efficiency under different experimental variables were analyzed. 


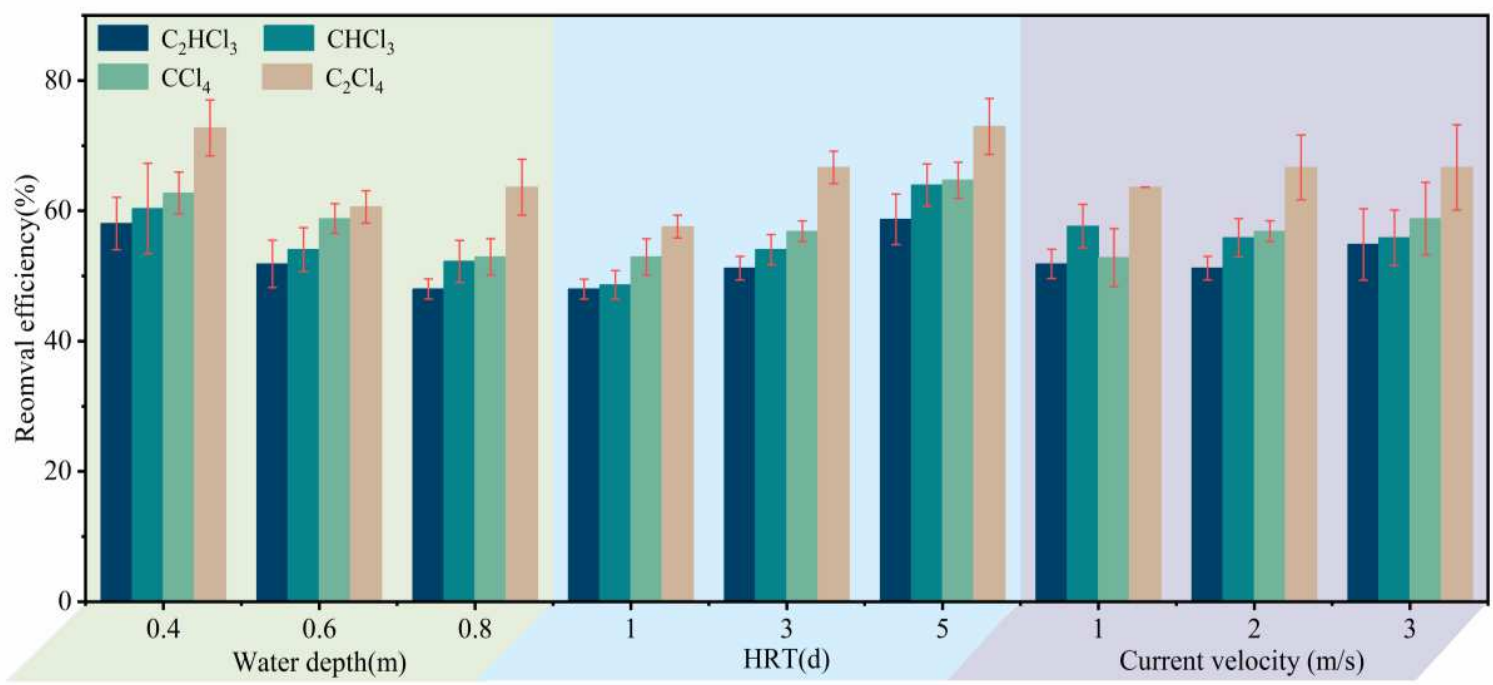

211

212

Fig.4 The VHCs removal efficiency under different influencing factors

As is shown in the Fig.4, the removal efficiency of four VHCs existed differences, which

was associated with the change of influencing factors. The average removal efficiency of

$\mathrm{CHCl}_{3}, \mathrm{CCl}_{4}, \mathrm{C}_{2} \mathrm{HCl}_{3}$ and $\mathrm{C}_{2} \mathrm{Cl}_{4}$ in the in-situ restoration reactor was $45.95 \%-70.27 \%$,

$47.06 \%-70.59 \%, 45.16 \%-67.74 \%$, and $54.55 \%-81.82 \%$, respectively. For the sake of

determine the effect on experimental factors, significance tests of orthogonal experiment

results were analyzed. The results were shown in the Table.3.

Table 3 Orthogonal matrix and significance test of results

\begin{tabular}{|c|c|c|c|c|c|}
\hline \multicolumn{2}{|c|}{ Number of groups } & Water depth (m) & HRT (d) & Current velocity $(\mathrm{m} / \mathrm{s})$ & \multirow{2}{*}{$\begin{array}{c}\begin{array}{c}\text { Fictitious } \\
\text { factors }\end{array} \\
1\end{array}$} \\
\hline 1 & & 0.4 & 1 & 1 & \\
\hline 2 & & 0.4 & 3 & 2 & 2 \\
\hline 3 & & 0.4 & 5 & 3 & 3 \\
\hline 4 & & 0.6 & 1 & 2 & 3 \\
\hline 5 & & 0.6 & 3 & 3 & 1 \\
\hline 6 & & 0.6 & 5 & 1 & 2 \\
\hline 7 & & 0.8 & 1 & 3 & 2 \\
\hline 8 & & 0.8 & 3 & 1 & 3 \\
\hline 9 & & 0.8 & 5 & 2 & 1 \\
\hline \multirow{8}{*}{$\begin{array}{c}\text { Water } \\
\text { depth(m) }\end{array}$} & Name & $\mathrm{CHCl}_{3}$ & $\mathrm{CCl}_{4}$ & $\mathrm{C}_{2} \mathrm{HCl}_{3}$ & $\mathrm{C}_{2} \mathrm{Cl}_{4}$ \\
\hline & $K_{1}$ & 181.08 & 188.23 & 174.19 & 218.19 \\
\hline & $K_{2}$ & 162.16 & 176.47 & 155.59 & 181.83 \\
\hline & $K_{3}$ & 156.76 & 158.82 & 143.99 & 190.92 \\
\hline & $\bar{K}_{1}$ & 60.36 & 62.74 & 58.06 & 72.73 \\
\hline & $\bar{K}_{2}$ & 54.05 & 58.82 & 51.86 & 60.61 \\
\hline & $\bar{K}_{3}$ & 52.25 & 52.94 & 48 & 63.64 \\
\hline & $R$ & 24.32 & 29.41 & 30.2 & 36.36 \\
\hline
\end{tabular}




\begin{tabular}{cccccc} 
& $K_{1}$ & 145.95 & 158.82 & 143.99 & 172.74 \\
& $K_{2}$ & 162.16 & 170.58 & 153.67 & 200.01 \\
HRT (d) & $K_{3}$ & 191.89 & 194.12 & 176.11 & 218.9 \\
& $\bar{K}_{1}$ & 48.65 & 52.94 & 48 & 57.58 \\
& $\bar{K}_{2}$ & 54.05 & 56.86 & 51.22 & 66.67 \\
& $\bar{K}_{3}$ & 63.96 & 64.71 & 58.7 & 72.97 \\
& $R$ & 45.94 & 35.3 & 32.12 & 46.16 \\
& $K_{1}$ & 172.97 & 176.47 & 155.59 & 190.92 \\
Current & $K_{2}$ & 167.57 & 170.58 & 153.67 & 200.01 \\
velocity & $K_{3}$ & 167.57 & 176.47 & 164.51 & 200.01 \\
(m/s) & $\bar{K}_{1}$ & 57.66 & 52.82 & 51.86 & 63.64 \\
& $\bar{K}_{2}$ & 55.86 & 56.86 & 51.22 & 66.67 \\
& $\bar{K}_{3}$ & 55.86 & 58.82 & 54.84 & 66.67 \\
& $R$ & 5.4 & 5.89 & 10.84 & 9.09 \\
& $K_{1}$ & 162.16 & 176.46 & 154.83 & 200.01 \\
Fictitious & $K_{2}$ & 167.57 & 170.59 & 156.76 & 190.92 \\
factors & $K_{3}$ & 170.27 & 176.47 & 162.18 & 200.01 \\
& $\bar{K}_{1}$ & 54.05 & 58.82 & 51.61 & 66.67 \\
& $\bar{K}_{2}$ & 55.86 & 56.86 & 52.25 & 63.64 \\
& $\bar{K}_{3}$ & 56.76 & 58.82 & 54.06 & 66.67 \\
\hline & $R$ & 8.11 & 5.88 & 7.35 & 9.09 \\
\hline
\end{tabular}

221 which was calculated by Eq.(2) and Eq.(3) in this experiment.

222

$$
S S_{t}=\frac{1}{r} \sum_{i=1}^{k} K_{i j}{ }^{2}-T
$$

$$
T=\frac{S^{2}}{n}
$$

$225 S S_{t}-$ Sum of square deviance with each factors

$226 r, k-$ The repeat times of each level, the number of levels with each factor

$227 \quad K_{i j}-$ Total indicators of each factor level

$228 T-$ Sum of all index

$229 n$-Number of experiments $(n=9)$

230

$$
N=d f_{a}=d f_{b}=d f_{c}=d f_{d}=m-1
$$

$$
M S_{t}=\frac{S S_{t}}{d f_{t}}
$$


$M S_{t}$ - Variance of each factor

According to Eq.(4) and Eq.(5) calculated the variance of each factor. Final F value was obtained through Eq. (6) and identify the significance on the factors.

$$
F_{t}=\frac{M S_{t}}{M S_{\mathrm{e}}}
$$

Using the forgoing formulas carried out the experiment data analysis of significance test.

The critical value $F_{0.05}(2,4)$ of 19.247 was selected. The results were list in Tab. 4.

Table 4 ANOVA of the orthogonal experimental results

\begin{tabular}{|c|c|c|c|c|c|c|c|c|}
\hline \multicolumn{2}{|c|}{ Source of variation } & SS & $\begin{array}{c}\mathrm{DO} \\
\mathrm{F}\end{array}$ & MS & $\mathrm{F}$ & $\mathrm{F}_{\mathrm{c} 1}$ & $\mathrm{~F}_{\mathrm{c} 2}$ & Sig \\
\hline \multirow{4}{*}{$\mathrm{CHCl}_{3}$} & Water depth & 108.732 & 2 & 457.45 & 80.466 & 19.247 & 9.243 & $* *$ \\
\hline & HRT & 361.902 & 2 & 180.951 & 31.83 & 19.247 & 9.243 & $* *$ \\
\hline & $\begin{array}{l}\text { Current } \\
\text { velocity }\end{array}$ & 914.899 & 2 & 54.336 & 9.558 & 19.247 & 9.243 & $*$ \\
\hline & $\begin{array}{l}\text { Fictitious } \\
\text { factors }\end{array}$ & 11.37 & 2 & 5.685 & & & & \\
\hline \multirow{4}{*}{$\mathrm{CCl}_{4}$} & Water depth & 146.085 & 2 & 73.046 & 18.948 & 19.247 & 9.243 & $*$ \\
\hline & HRT & 215.391 & 2 & 107.696 & 28.082 & 19.247 & 9.243 & $* *$ \\
\hline & $\begin{array}{l}\text { Current } \\
\text { velocity }\end{array}$ & 7.709 & 2 & 3.855 & 1 & 19.247 & 9.243 & \\
\hline & $\begin{array}{l}\text { Fictitious } \\
\text { factors }\end{array}$ & 7.67 & 2 & 3.835 & & & & \\
\hline \multirow{4}{*}{$\mathrm{C}_{2} \mathrm{HCl}_{3}$} & Water depth & 154.729 & 2 & 77.365 & 15.85 & 19.247 & 9.243 & * \\
\hline & HRT & 180.994 & 2 & 90.497 & 18.698 & 19.247 & 9.243 & $*$ \\
\hline & $\begin{array}{l}\text { Current } \\
\text { velocity }\end{array}$ & 22.306 & 2 & 11.153 & 2.304 & 19.247 & 9.243 & \\
\hline & $\begin{array}{l}\text { Fictitious } \\
\text { factors }\end{array}$ & 9.68 & 2 & 4.84 & & & & \\
\hline \multirow{4}{*}{$\mathrm{C}_{2} \mathrm{Cl}_{4}$} & Water depth & 238.703 & 2 & 119.352 & 12.986 & 19.247 & 9.243 & $*$ \\
\hline & HRT & 452.319 & 2 & 226.16 & 24.607 & 19.247 & 9.243 & $* *$ \\
\hline & $\begin{array}{l}\text { Current } \\
\text { velocity }\end{array}$ & 18.382 & 2 & 9.191 & 1 & 19.247 & 9.243 & \\
\hline & $\begin{array}{l}\text { Fictitious } \\
\text { factors }\end{array}$ & 18.382 & 2 & 9.191 & & & & \\
\hline
\end{tabular}

SS, sum of squares; DOF, total degree of freedom; MS, mean square; $F_{c 1}$, critical $F$ value at $\alpha$ level of $0.05 ; \mathrm{F}_{\mathrm{c} 2}$, critical $\mathrm{F}$ value at $\alpha$ level of $0.1 ; \mathrm{Sig}$, significance (** Extremely significant influence $\mathrm{p}<0.05$; * Significant influence $\mathrm{p}<0.1$ )

As seen in Table.4, when the water depth was $0.4 \mathrm{~m}$, the HRT was $5 \mathrm{~d}$ and the current velocity was $1 \mathrm{~m} / \mathrm{s}$, VHCs removal efficiencies could reach favorable value. The factor of HRT was the most influential factor in the removal efficiency of $\mathrm{CHCl}_{3}, \mathrm{CCl}_{4}$ and $\mathrm{C}_{2} \mathrm{Cl}_{4}$, and 
water depth showed an extremely notable role on the $\mathrm{CHCl}_{3}$ removal in the experiment $(\mathrm{p}<0.05)$. The sufficient contact time between the reactor and wastewater was directly affected by HRT, which involved in alter the accumulation of aquatic ecosystems in reactor, and the value of it should be extended appropriately to promote the good performance ( $\mathrm{Su}$ et al., 2009). Besides, the factor of water depth also showed extremely significance on $\mathrm{CHCl}_{3}$ removal $(\mathrm{p}<0.05)$ and exhibited significant influence on $\mathrm{CCl}_{4}, \mathrm{C}_{2} \mathrm{HCl}_{3}$, and $\mathrm{C}_{2} \mathrm{Cl}_{4}(\mathrm{p}<0.1)$. Water depth was used as a measure of treatment volume, which related to not only the total water volume, but also influence the active quantity of the in-situ restoration system. Mathon et al (2019) reported that the degradation of micropollutants were significant decrease corresponding to the increase of water level, which was in line with our results. And the effect of reactor existed a possible link with the light intensity, which was affected by the water depth. The appropriate light intensity was conducive for promoted potential function on the plants, such as biological function and metabolism status. The plants grow particularly well with the relatively low water depth, the removal of pollutants could be accelerated when the optimal condition was obtained.

Current velocity had a significant influence on the $\mathrm{CHCl}_{3}$ removal, but it was not obvious on the others pollutants removal effects. Some previous studies showed that a low current velocity was promoted to flocculate and precipitate of pollutants in damaged river, which was conducive to the removal of pollutants (Navarro-Ortega et al., 2010; Pan et al., 2016). The variation on the current velocity affected the reactor by altering the degree of architecture of submerged macrophytes, influencing the association on leaf-water interface and adjusting the attachment of bacteria, comprehensively. The significant influence of current velocity was 
relatively low might be the distribution of VHCs was relatively stable under low current velocity. In addition, both sum of squares and $\mathrm{R}$ value of fictitious factors was relatively low indicated that no significant interaction effects existed among the variables (Xiong et al., 2020). The situation mainly because extended HRT, decreased current velocity could strengthen interaction between the restoration area and polluted river water, which was conductive to the adsorption of VHCs through plants and optimizing mass transfer by epiphytic biofilms (Li et al., 2018). The decrease on current velocity would weaken the influence on flow shear, adjusting the attachment and distribution of biofilms. The increase of water depth increased the treatment volume with in situ restoration reactor, exacerbated the formation of anaerobic environment and the hydraulic dead zone (Liu et al., 2016), which would cause the removal efficiency improve more difficult.

In addition, the F value in the variance analysis showed that HRT and water depth had a significant impact on the VHCs removal, and the order of the factors could be summarized as HRT, water depth and current velocity for in situ restoration reactor. The evaluation index of orthogonal test was contact with its impact on the results, which exhibited positively correlation on the two indexes. Both HRT and water depth exhibited the highest significance on the VHCs removal, but current velocity had a bad correlation. However, the accuracy of orthogonal experiment seemed to be lower than single factor analyses, which was the unavoidable disadvantage of this scheme. The reason for the situation could be attributed to the restriction of the level setting (Guo et al., 2017). Considering the shortcomings of the orthogonal test, the further research should be added parallel experiment to improve the accuracy of orthogonal experiment. 


\subsection{Photosynthetic fluorescence characteristics upon plants}

291

The photosynthesis ability of plants was a drive factor that regulate the growth and

292 metabolism, implied the net assimilation rates of plants, which characterized the plant stress

293 responses at the same (Zhang et al., 2020b). Rapid light curves (RLC) are plots of mechanisms

294 of photosynthesis for 10s, it could reflect the influence of differ environmental factors on the

295 photosynthetic reactions (White \& Critchley, 1999). The plots were measured with DIVING-

PAM-II, the results were shown in the Fig.5.
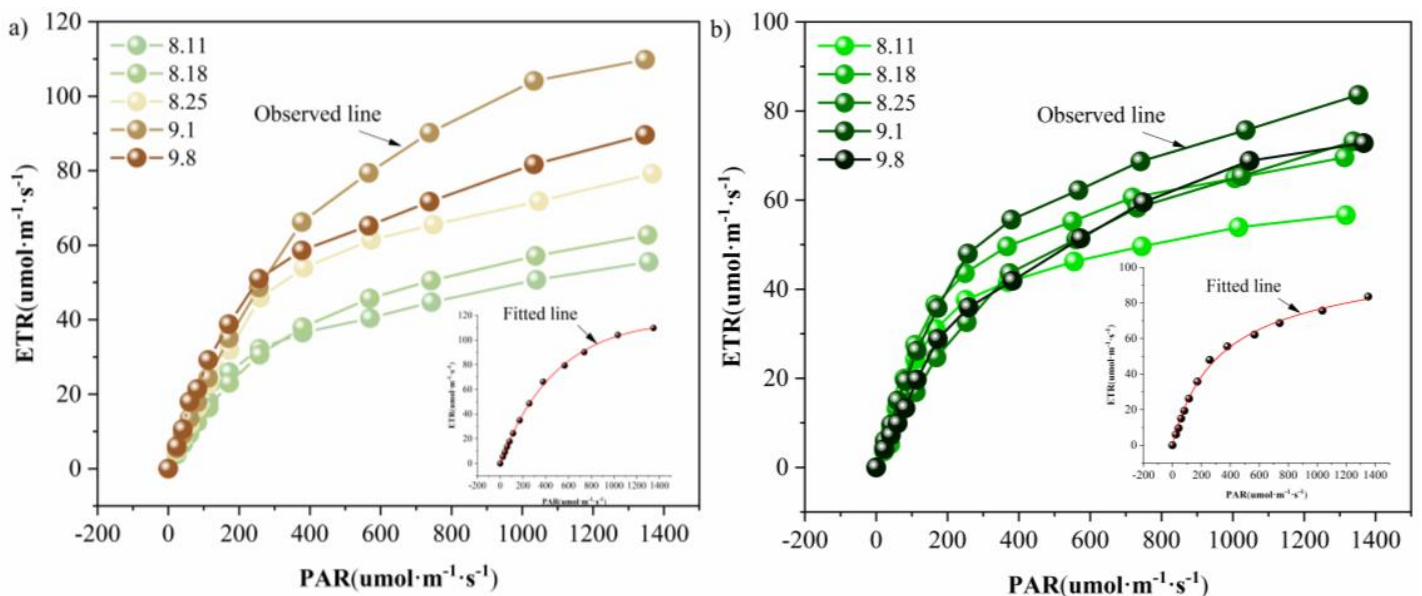

297
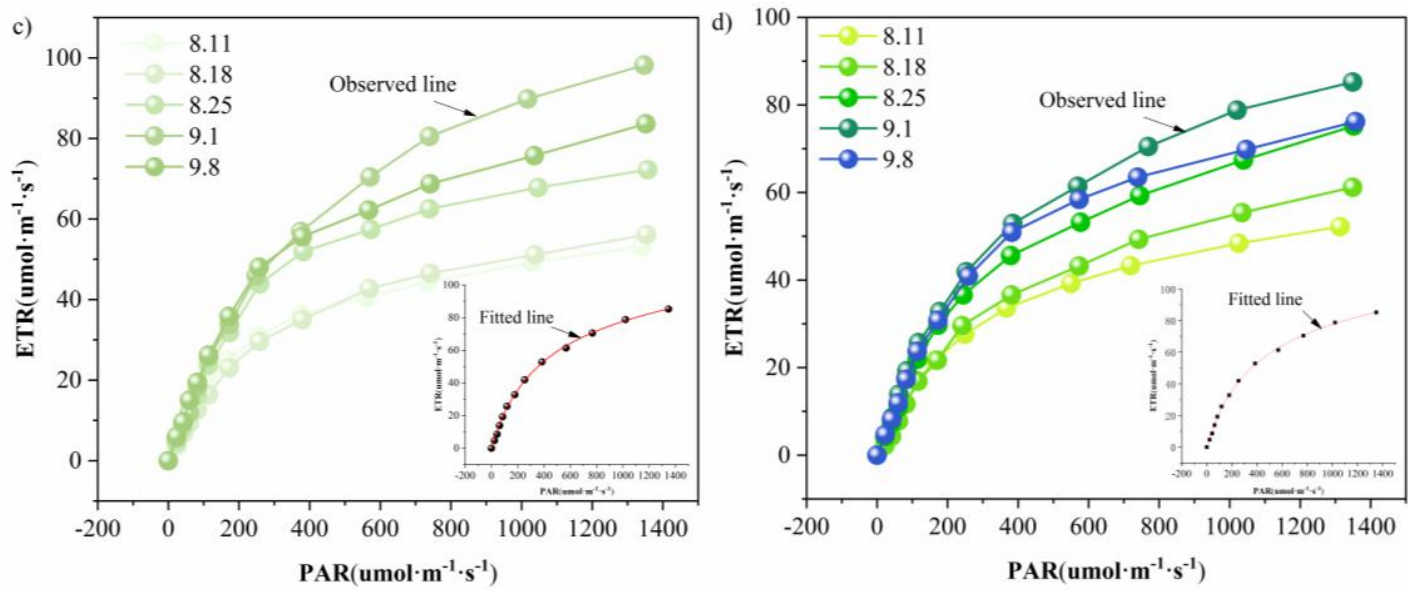

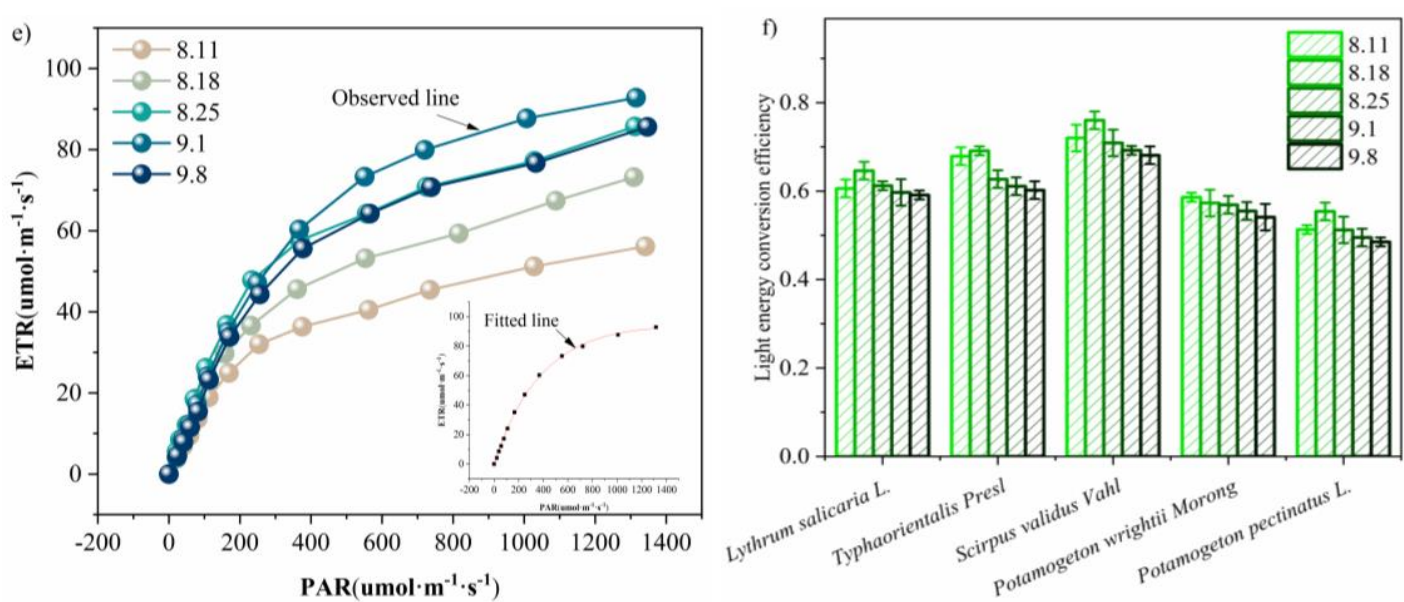

Fig.5 Photosynthetic fluorescence characteristics upon plants (a. Lythrum salicaria L. b.

As is shown in Fig.5, the RLCs of different plants were obtained under similar temperature $\left(20^{\circ} \mathrm{C}\right)$, which indicated the plants existed some difference at the intrinsic characteristics of photosynthetic ability and electron transport, especially in stressful environment. On the whole, the relative electron transfer efficiency (ETR) of plants increased with the increase of photosynthetically active radiation and reaction time at the on the peak value, and then decrease slightly. This phenomenon on plants caused by the physiological mechanism for the adaption to environmental stress. The increase in ETR for the several plants were considerably and the values of Lythrum salicaria L. was the highest, which exhibited it had the excellent pollutant resistance. The variation on ETR was linked with the adjustment on growth characteristics and photosynthesis pigments for plants (Yaghoubian et al., 2016). The VHCs damaged the photosynthetic apparatus was a cumulative process in plants, which were consistent with the change on RLCs under different experiment plants in our experiment (Hou et al., 2018). In addition, five kinds of experimental plants existed 
significance difference $(\mathrm{p}<0.01)$, which supported that prominent diversity exists in the adaptation abilities for different types of plants.

As is shown in Fig.5-f), it was found that the $F_{v} / F_{m}$ values of experiment plants were decline with the time extended, which showed the physiological state of the plant was inhibited to a certain extent. The variation on the $\mathrm{F}_{\mathrm{v}} / \mathrm{F}_{\mathrm{m}}$ value was related to the conversion efficiency of photosystem II, which was linked with non-cyclic electron transport rates and implied the assimilation capability of plants with the help of light energy (Takahashi \& Badger, 2011). The decline of $F_{v} / F_{m}$ value supported that there existed some damage in the photosynthetic machinery of experiment plants. In addition, Krall et al (2010) proposed the $\mathrm{F}_{\mathrm{v}} / \mathrm{F}_{\mathrm{m}}$ value near 0.8 was conducive for exploited full potential on the photosynthetic activity and productivity of plants. All the $\mathrm{F}_{\mathrm{v}} / \mathrm{F}_{\mathrm{m}}$ valve of experiment plants lower than 0.8 , which was demonstrated the results that physiological state of the plants was endangered.

Using the presetting program of fluorescence induction curves and light curves, the parameters of the photosynthesis were obtained. According to the according to the model of Frankenbach and SeroDio (2017), the best RLCs of five kinds of experiment plants were fitted by the Eq. (7). transfer rate $\left(E T R_{\max }\right)$, the initial slope $(\alpha)$ and half-saturation light intensity $\left(I_{k}\right)$ was calculated by the Eq. (8), Eq. (9) and Eq. (10), respectively.

$$
E T R=\frac{P A R}{\mathrm{a} \cdot \mathrm{PAR}^{2}+\mathrm{b} \cdot \mathrm{PAR}+\mathrm{c}}
$$

And the detailed parameters of curves included the maximum photosynthetic electron 
Table 5 Detailed parameters of rapid light curves equation upon experiment plants

\begin{tabular}{ccccc}
\hline Name & Fast light curve equation & $a$ & $E^{2} R_{\max }$ \\
\hline $\begin{array}{c}\text { Lythrum } \\
\text { salicaria } L .\end{array}$ & $E=\frac{P}{1.039 \mathrm{E}^{-6} \cdot \mathrm{P}^{2}+0.005 \cdot \mathrm{P}+4.013}$ & 0.249 & 211.421 \\
\hline $\begin{array}{c}\text { Typhaorientalis } \\
\text { Presl }\end{array}$ & $E=\frac{P}{1.615 E^{-6} \cdot P^{2}+0.006 \cdot P+3.836}$ & 0.261 & 171.238 \\
\hline $\begin{array}{c}\text { Scirpus validus } \\
\text { Vahl }\end{array}$ & $E=\frac{P}{5.562 E^{-8} \cdot \mathrm{P}^{2}+0.007 \cdot P+3.82}$ & 0.262 & 137.175 \\
\hline $\begin{array}{c}\text { Potamogeton } \\
\text { wrightii Morong }\end{array}$ & $E=\frac{P}{6.411 E^{-7} \cdot P^{2}+0.01 \cdot P+3.67}$ & 0.272 & 101.423 \\
\hline $\begin{array}{c}\text { Potamogeton } \\
\text { pectinatus } L .\end{array}$ & $E=\frac{P}{4.331 E^{-7} \cdot P^{2}+0.01 \cdot P+3.111}$ & 0.321 & 95.788 \\
\hline
\end{tabular}

pectinatus $L$. was highest, and the value of Potamogeton wrightii Morong was the second largest,

347 which exhibited that they had the strongest tolerance to strong light. The phenomenon 
353 plants, which hinted the plant had superior stress resistance (Brestic \& Zivcak, 2013).

\section{$354 \quad 3.3$. The microbial community structures}

The removal of VHCs in in situ restoration reactor mainly relies on biological function,

356 which was similar with the pollutant removal role on constructed wetland (Tang et al., 2020).

357 in situ restoration reactor of different plants and substrates can induce changes in microbial 358 community structure, which influenced on the energy and complex compounds 359 transformation efficiencies. Give full consideration to the characteristics of the fillers, the 360 samples of ceramsite and zeolite were collected during the experiment and analyzed in the 361 end. The results were shown in the Fig.6. 

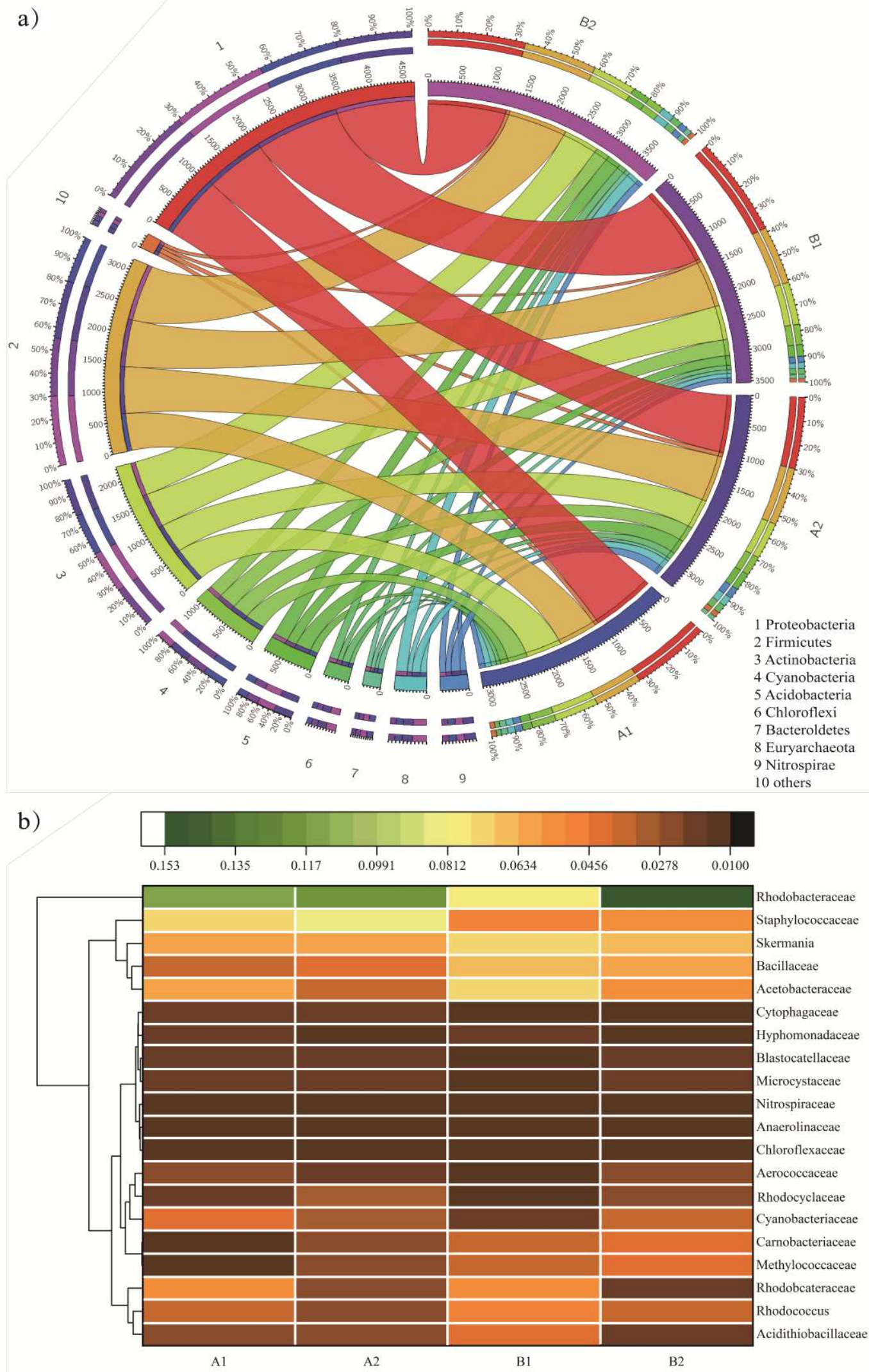

363 Fig.6. Relative abundance of the main microbial composition (a) phyla level (b) Family level 
The distribution of microorganisms at phyla level in fillers are shown in the Fig.6. A1 and $\mathrm{A} 2$ are ceramsites at the $9 \mathrm{~d}$ and $27 \mathrm{~d}, \mathrm{~B} 1$ and B2 are zeolites at the $9 \mathrm{~d}$ and $27 \mathrm{~d}$, and a total of $3101,3320,3530,3805$ OTUs were identified from the four samples, respectively. Generally, 10 phyla of the bacterial communities were contained in the samples. The biomass samples taken from the in-situ restoration reactor were dominated by Proteobacteria, Firmicutes, Cyanobacteria, and Actinobacteria respectively at the phylum level, which was account for over half of the microbial community. These microbial communities were always play an important role in the degradation of organic matter, which had been found in the rhizosphere zone usually (Li et al., 2020a; Man et al., 2020). Proteobacteria and Firmicutes had been reported that included various bacteria with hydrolysis and could degrade complex compounds, which was common flora of macrophyte rhizospheres in the fillers of wetland (Huang et al., 2020; Yang et al., 2020). Cyanobacteria was a common component of soil-root interface in wetland substrate, in which some species involved in nutrients removal (Mandal et al., 1992). Besides, Actinobacteria were quotidian microorganisms in wetland ecosystem, whose existence was advantageous to the recycling of refractory biomaterials (Hassan et al., 2017).

As is shown in the Fig.6-a), after 18 days of operation of the in-situ restoration reactor, the distribution of biomass was more balanced both in zeolites and ceramsites. There are some previous researches supported that the microbial community structure would be evolved in order to constantly adapt to the variation of the environment, which might be related to the decrease of Proteobacteria (Kobayashi et al., 2020; Zheng et al., 2020). Some of Acinobacteria had specific degradation capacity, such as Streptomyces, Rhodococcus, which could 
386

387

immensely helpful for the degradation of recalcitrant compound (Fatahi-Bafghi, 2019). The decrease of the relative abundance of Actinobacteria may be related to the acidogenic decomposition process on the VHCs during the experiment. Firmicutes contained many microbes, which was responsible for the structure on the bacterial colony. The increase of Firmicutes implied that the stability of bacterial biofilm was improved in the fillers (Chouari et al., 2005). Additionally, the content of Chloroflexi increased in the fillers, whose existence was advantageous to the dichlorination process in the reactor. In fact, Firmicutes and Chloroflexi contained a number of microorganisms had with the potential to biodegrade VHCs, such as Cyanobacteria, Bacillus and Staphylococcus, and the change of the two phylum was conducive to the improvement of in situ restoration reactor performance (Guo et al., 2020; Yuan et al., 2017). According to the changes of Bacteroidetes, it was founded that there existed different on the content of zeolites and ceramsites. Wolinska et al (2017) found Bacteroidetes could be used as a biological index of microbial community structure, and the amount of it would increase when the bacterial community encountered poor environment. And the amount of Bacteroidetes increased in the zeolites was conformed to the characteristics of materials, the fillers could adsorb considerable VHCs. And because the zeolites had better adsorption capacity, generous VHCs would accumulate on this filler, which exacerbated the difficult on the living of microorganisms. In addition, some researchers have been reported that Acidobacteria, Cyanobacteria and Nitrospirae were essential factors in wetland substrate, which could maintain the function of wetland (Li et al., 2020b). All these floras were observed as the dominant bacteria in experiment reactor, while the proportion of these phylum were declined in the later period of experiment. It was proved that there existed 
certain adjustment on the microbial community to suit the change of the influent.

As is shown in the Fig.6-b), 20 species were determined as dominant bacteria, numbers from Rhodobcateraceae, Staphylococcaceae, Skermania were most frequently detected at the family level. Some previous research has been reported that some bacterial strains belong to Rhodobcateraceae showed excellent capacity to biodegrade a wide range of organic compound, which were used as bioremediation (Cappelletti et al., 2020). It was the most abundant family in zeolites and ceramsites, no matter in initial or last stage during the experiment. Staphylococcaceae was the second most abundant phylum in our results and the relative abundance of Skermania was followed closely. Staphylococcaceae and Skermania included a group of microorganisms had nutrients removal capacity, often as a basic component of activated sludge or wetland structure (Milobedzka \& Muszynski, 2015; Wang et al., 2016). Furthermore, Methylococcaceae was predominance bacterial group, some researchers demonstrated that it contained some types methanotrophs that could utilize the methane to gain energy (Albers et al., 2015). The proportion of Methylococcaceae at the family level was promoted obviously, which was probably related to the affluent $\mathrm{CH}_{4}$ originated from the reductive action on the VHCs decomposition.

Additionally, both the number of Bacillaceae and Cytophagaceae exhibited that the opposite trends in the two fillers, which showed the enrichment in the ceramsites and decline in the zeolites. It appeared be link with the active bacteria were affected by the distribution on the pollutant concentration. The relative abundance of Chloroflexaceae was clearly more abundant in the later stage on the experiment. It has been widely reported that Chloroflexaceae was a kind of photosynthetic bacteria, which might be live close vicinity to 
the primary producers and along with the abundance around the roots (Nubels et al., 2002).

We believe the positive change on it connected with the diffusion on the plant roots. In addition, the number of Rhodocyclaceae in the fillers increased, which degraded trichloroethene in the in-situ restoration reactor and could assist dechlorinate carbon tetrachloride to form $\mathrm{CH}_{4}$ and $\mathrm{CO}_{2}$ (ZivEl et al., 2011). The abundance of family Skermania and Rhodococcus decreased slightly, both of the two kinds of microorganisms from the phylum Acidobacteria, which is consistent with some previous studies that Acidobacteria was difficult to use VHCs cometabolism (Maaike et al., 2015).

Overall, the results showed that the change of polluted river water led to the change of microbial community structure. In fact, the microbial communities would make a great response to adapt to the changes of environment, which was in line with the previous experimental results, and this situation could be described to two points. For one view, the microenvironment was regulated by rhizosphere of aquatic macrophytes. For another, the microorganisms were stimulated by the actual polluted river water, which would enhance community diversity, especially under a relatively high nutrient status (Navel et al., 2012; Zhang et al., 2010). But on the whole, the dominant microbial community stay relatively stable under the diverse hydraulic conditions, which help the degradation and conversion of the VHCs and was essential to the dechlorinating function of the in-situ reactor.

\subsection{Mechanism of VHCs degradation}

VHCs degradation needed multiple interactions, particularly in the in-situ restoration reactor. In-situ ecological restoration reactor was adopted to treat the VHCs in polluted river water, the processes were shown in the Fig.7. 


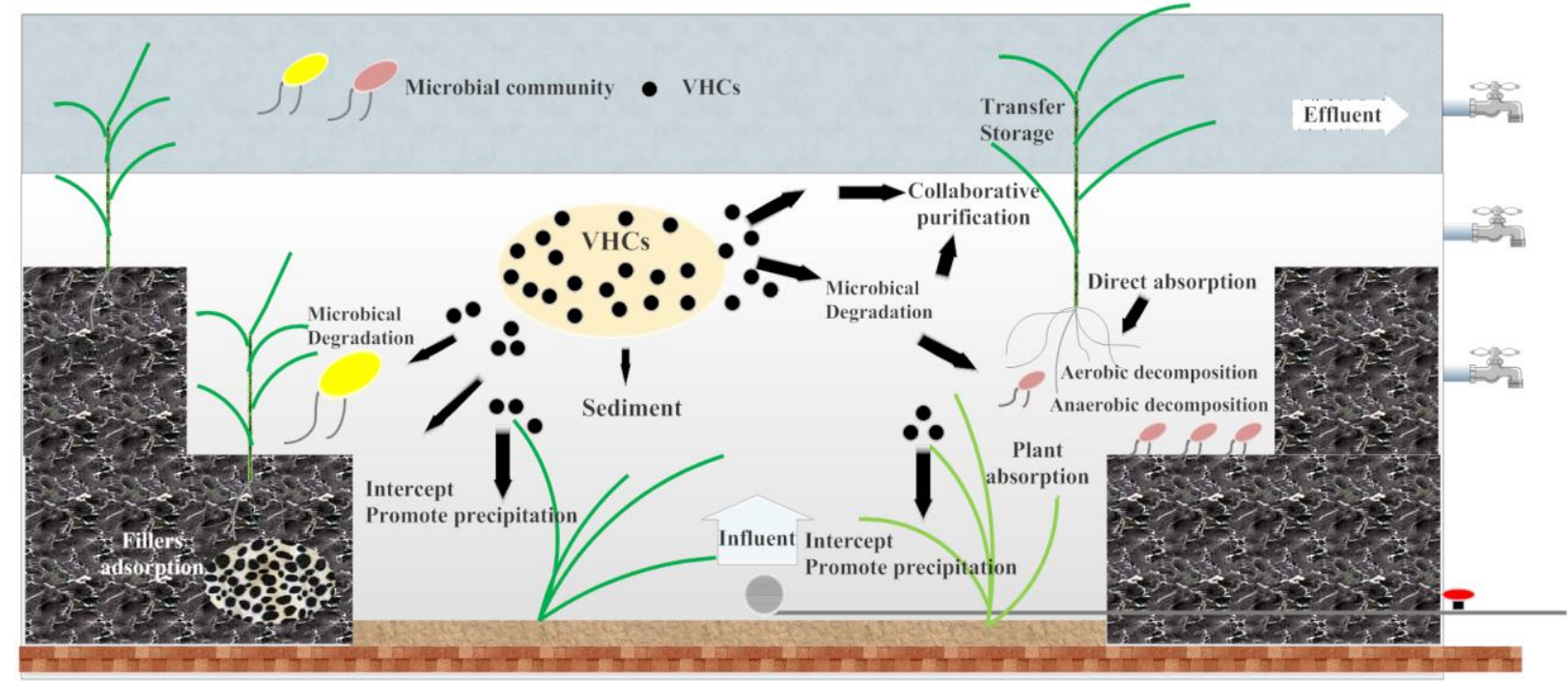

Fig.7 Degradation mechanism of VHCs in reactor

its function exertion. The degradation reaction process of dehalogenation in plants were complex. Under the action of peroxidase, the conversion of VHCs was usually completed by

substitution reaction. In this experiment, the purification effect of plants depended on the

process of gas deposition and particulate matter deposition. On the one hand, through the

exchange of gas deposition between the pores and the liquid surface, the migration trajectory

reduced by macrophyte and the settlement of pollutant particles could be promoted by the way of particle sedimentation.

The micropores structure of the filler was helpful to adsorb the small molecule pollutant particles, which cause the separation of VHCs from volatile organic compounds (Li et al., 2020c). In addition, adsorption is a self-energy reduction process. According to the second law of 

(14), and Eq. (15):

$$
\begin{gathered}
\mathrm{CCl}_{4}+2 \mathrm{H}_{2} \mathrm{O} \rightarrow \mathrm{CHCl}_{3}+\mathrm{Cl}^{-}+\mathrm{H}^{+}+\mathrm{HCOOH} \\
2 \mathrm{CHCl}_{3}+2 \mathrm{H}_{2} \mathrm{O} \rightarrow \mathrm{CH}_{2} \mathrm{Cl}_{2}+\mathrm{HCOOH}+2 \mathrm{Cl}^{-}+2 \mathrm{H}^{+} \\
2 \mathrm{CH}_{2} \mathrm{Cl}_{2}+2 \mathrm{H}_{2} \mathrm{O} \rightarrow \mathrm{CH}_{3} \mathrm{Cl}+\mathrm{HCOOH}+3 \mathrm{Cl}^{-}+3 \mathrm{H}^{+} \\
2 \mathrm{CH}_{3} \mathrm{Cl}+2 \mathrm{H}_{2} \mathrm{O} \rightarrow \mathrm{CH}_{4}+\mathrm{HCOOH}+2 \mathrm{Cl}^{-}+4 \mathrm{H}^{+} \\
2 \mathrm{C}_{2} \mathrm{HCl}_{3}+4 \mathrm{H}_{2} \mathrm{O} \rightarrow 2 \mathrm{CO}_{2}+\mathrm{C}_{2} \mathrm{H}_{4}+6 \mathrm{Cl}^{-}+6 \mathrm{H}^{+} \\
2 \mathrm{C}_{2} \mathrm{Cl}_{4}+4 \mathrm{H}_{2} \mathrm{O} \rightarrow 4 \mathrm{CO}_{2}+8 \mathrm{Cl}^{-}+8 \mathrm{H}^{+}
\end{gathered}
$$

479

\section{Conclusions}

Through outdoor simulation testing, in in situ restoration method was applied to degrade VHCs of polluted river water, which showed that it was feasible. Favorable removal effect of $\mathrm{CHCl}_{3}, \mathrm{CCl}_{4}, \mathrm{C}_{2} \mathrm{HCl}_{3}$ and $\mathrm{C}_{2} \mathrm{Cl}_{4}$.could be obtained through in situ ecological restoration. In the experiment, orthogonal tests were applied to evaluated different influencing factors. The findings in this research suggested that when the water depth was $0.4 \mathrm{~m}$, the HRT was $5 \mathrm{~d}$ and 
the current velocity was $1 \mathrm{~m} / \mathrm{s}$, VHCs removal efficiencies could achieve favorable value, the removal efficiency of $\mathrm{CHCl}_{3} \mathrm{CCl}_{4}, \mathrm{C}_{2} \mathrm{HCl}_{3}$ and $\mathrm{C}_{2} \mathrm{Cl}_{4}$.could reach $70.27 \%, 70.59 \% 67.74 \%$ and $81.82 \%$, respectively. Besides, F test results exhibited that HRT and water depth were significantly related to the removal efficiency of reactor. The RLCs of plants were analyzed by DIVING-PAM-II, which prominent diversity exists in the adaptation abilities for different types of plants, but the physiological state of the plants was endangered by VHCs of polluted river water in all.

Moreover, the microbial community structure and diversity of reactor were regulated to more balance and adapt to the variation characteristics of complex polluted river water conditions. The microbial community structures of fillers were tested by high-throughput sequencing, the findings supported that the proportion on the reductive dechlorination bacterial of VHCs was improved. And there existed a slightly improvement on the relative abundance of Rhodocyclaceae, which might be related to it could promote VHCs degradation. In general, in situ ecological restoration had a good potential performance on pollutants removal in polluted river water. The results showed that technology provided a green and low consumption approach for the maintenance and purification on polluted river water.

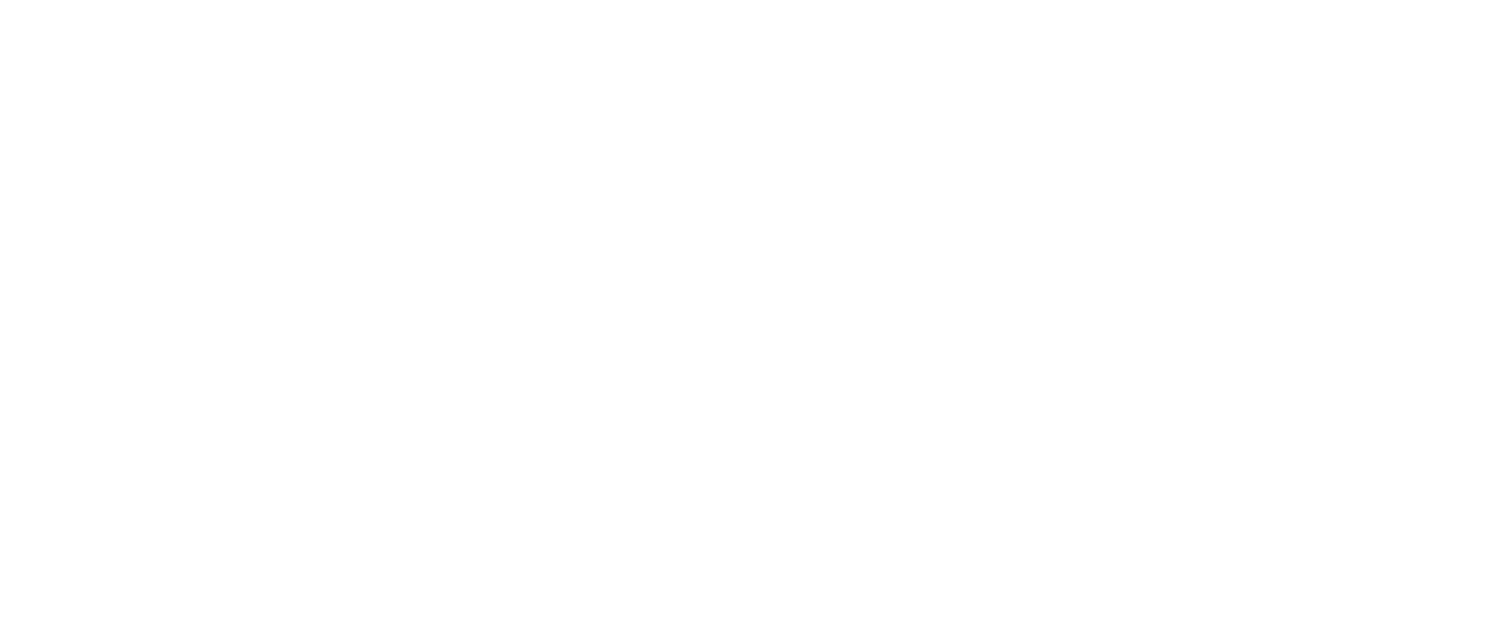


\The authors declare that they have no known competing financial interests or personal relationships that could have appeared to influence the work reported in this paper. considered as potential competing interests:

Author contributions:

522 Jia Wang: Validation, Visualization, Software, Data curation, Writing-Original Draft.

523 Shuangrong Wu: Supervision, Visualization, Writing-Review \& Editing..

524 Qi Yang: Conceptualization, Methodology, Software, Investigation, Writing-Review \&

525 Editing.

526 Yonggang Gu: Resources, Formal analysis, Supervision.

527 Peijing Wang: Investigation, Data curation.

528 Zhaoxin Li: Writing-Review \& Editing.

529 Lei Li: Software, Investigation.

530 Thank you.

531 Yours sincerely,

$532 \quad$ Yonggang $\mathrm{Gu}$

\section{Ethical approval}

$534 \quad$ Not applicable.

\section{Consent to Participate}

$536 \quad$ I declare here that all authors approve publish this paper.

537 Thank you.

538 Yours sincerely,

$539 \quad$ Yonggang $\mathrm{Gu}$ 
550

551

552

553

554

\section{Competing Tests}

The authors declare that they have no known competing financial interests or personal relationships that could have appeared to influence the work reported in this paper. Thank you.

\section{Funding}

Research and Demonstration on Key Technologies of Urban Landscape River Water System Connection and Typical Black and Stinky River Treatment in Northern Area (2017ZX07103-001) and the National Science and Technology Major Project of China (2015ZX07406005).

\section{Availability of data and materials}

$$
\text { Not applicable. }
$$

\section{Acknowledgements}

This work was supported by Research and Demonstration on Key Technologies of Urban Landscape River Water System Connection and Typical Black and Stinky River Treatment in Northern Area (2017ZX07103-001) and the National Science and Technology Major Project of China (2015ZX07406005).

\section{References}

Albers, C. N., Ellegaard-Jensen, L., Harder, C. B., Knudsen, B. E., Ekelund, F., Aamand, J., 2015. Groundwater Chemistry Determines the Prokaryotic Community Structure of Waterworks Sand Filters[J]. Environmental Science \& Technology, 49(2):839-46.

Anwar Sadat, M., Guan, Y., Zhang, D., Shao, G., Cheng, X., Yang, Y. 2020. The associations between river health and water resources management lead to the assessment of river state. Ecological Indicators, 109. 
Brestic, M., Zivcak, M. 2013. PSII Fluorescence Techniques for Measurement of Drought and High Temperature Stress Signal in Crop Plants: Protocols and Applications. in: Molecular Stress Physiology of Plants, pp. 87-131.

Cappelletti, M., Presentato, A., Piacenza, E., Firrincieli, A., Turner, R.J., Zannoni, D. 2020. Biotechnology of Rhodococcus for the production of valuable compounds. Appl Microbiol Biotechnol, 104(20), 8567-8594.

Chouari, R., Le Paslier, D., Daegelen, P., Ginestet, P., Weissenbach, J., Sghir, A. 2005. Novel predominant archaeal and bacterial groups revealed by molecular analysis of an anaerobic sludge digester. Environmental Microbiology, 7(8), 1104-1115.

Dong, S., Feng, C., Cui, W., Chen, N., Liu, Y., Liu, T., 2018. Anaerobic Bioremediation Performance and Indigenous Microbial Communities in Treatment of Trichloroethylene/NitrateContaminated Groundwater[J]. Environmental Engineering Science, 35(4):311-322

Fatahi-Bafghi, M. 2019. Antibiotic resistance genes in the Actinobacteria phylum. Eur J Clin Microbiol Infect Dis, 38(9), 1599-1624.

Giripunje, M. D., Fulke, A. B., Meshram, P. U., 2015. Remediation Techniques for Heavy-Metals Contamination in Lakes: A Mini-Review. CLEAN - Soil, Air, Water, 43(9), 1350-1354.

Guo, C., Cui, Y., Dong, B., Luo, Y., Liu, F., Zhao, S., Wu, H. 2017. Test study of the optimal design for hydraulic performance and treatment performance of free water surface flow constructed wetland. Bioresour Technol, 238, 461-471.

Guo, Z., Kang, Y., Hu, Z., Liang, S., Xie, H., Ngo, H.H., Zhang, J. 2020. Removal pathways of benzofluoranthene in a constructed wetland amended with metallic ions embedded carbon. Bioresour Technol, 311, 123481. 
Hassan, S.S., Anjum, K., Abbas, S.Q., Akhter, N., Shagufta, B.I., Shah, S.A., Tasneem, U. 2017. Emerging biopharmaceuticals from marine actinobacteria. Environ Toxicol Pharmacol, 49, 3447.

Hirsch, R. M., Moyer, D., Archfield, S. A., 2010. Weighted Regressions on Time, Discharge, and Season (WRTDS), with an Application to Chesapeake Bay River Inputs. Journal of The American Water Resources Association, 46(5), 857-880.

Hou, X., Liu, G., Jiang, G., 2018. Metabolism of typical halogenated organic pollutants in plants. Scientia Sinica Chimica, 48(10), 1236-1246.

Huang, X., Yang, X., Zhu, J., Yu, J. 2020. Microbial interspecific interaction and nitrogen metabolism pathway for the treatment of municipal wastewater by iron carbon based constructed wetland. Bioresour Technol, 315, 123814.

Jagnow, G., Haider, K., Ellwardt, P. C..1977. Anaerobic dechlorination and degradation of hexachlorocyclohexane isomers by anaerobic and facultative anaerobic bacteria[J]. Archives of Microbiology, 115(3):285-292.

Jiang, Y., Li, Y., Zhang, Y., Zhang, X. 2017. Effects of HRT on the efficiency of denitrification and carbon source release in constructed wetland filled with bark. Water Sci Technol, 75(12), 2908-2915.

Kobayashi, Y., Ralph, T.J., Sharma, P., Mitrovic, S.M.J.M., Research, F. 2020. Influence of historical inundation frequency on soil microbes (Cyanobacteria, Proteobacteria, Actinobacteria) in semi-arid floodplain wetlands. 71.

Krall, J.P.J.P.P. 2010. Relationship between photosystem II activity and CO2 fixation in leaves. 86(1), $180-187$. 
Ladislas, S., El-Mufleh, A., Gérente, C., Chazarenc, F., Andrès, Y., Béchet, B., 2011. Potential of Aquatic Macrophytes as Bioindicators of Heavy Metal Pollution in Urban Stormwater Runoff. Water, Air, \& Soil Pollution, 223(2), 877-888.

Li, D., Zheng, B., Liu, Y., Chu, Z., He, Y., Huang, M. 2018. Use of multiple water surface flow constructed wetlands for non-point source water pollution control. Appl Microbiol Biotechnol, 102(13), 5355-5368.

Li, X., Li, Y., Li, Y., Wu, J. 2020a. Myriophyllum elatinoides growth and rhizosphere bacterial community structure under different nitrogen concentrations in swine wastewater. Bioresour Technol, 301, 122776.

Li, X., Wu, S., Yang, C., Zeng, G. 2020b. Microalgal and duckweed based constructed wetlands for swine wastewater treatment: A review. Bioresour Technol, 318, 123858.

Li, X., Zhang, L., Yang, Z., Wang, P., Yan, Y., Ran, J. 2020c. Adsorption materials for volatile organic compounds (VOCs) and the key factors for VOCs adsorption process: A review. Separation and Purification Technology, 235.

Liu, J.J., Dong, B., Guo, C.Q., Liu, F.P., Brown, L., Li, Q. 2016. Variations of effective volume and removal rate under different water levels of constructed wetland. Ecological Engineering, 95, $652-664$.

Long, Y., Wu, S., Xiao, Y., Cui, P., Zhou, H. 2018. VOCs reduction and inhibition mechanisms of using active carbon filler in bituminous materials. Journal of Cleaner Production, 181, 784-793.

Lu, G., Wang, B., Zhang, C., Li, S., Wen, J., Lu, G., Zhu, C., Zhou, Y., 2018. Heavy metals contamination and accumulation in submerged macrophytes in an urban river in China. Int $J$ Phytoremediation, 20(8), 839-846. 
Maaike, V, A., Van, O., Gera, H., Hundscheid, M., Runia, W. T., Hordijk, C. A., Wietse, D. B., 2015. Legacy effects of anaerobic soil disinfestation on soil bacterial community composition and production of pathogen-suppressing volatiles[J]. Frontiers in Microbiology, 6:701-716.

Man, Y., Wang, J., Tam, N.F., Wan, X., Huang, W., Zheng, Y., Tang, J., Tao, R., Yang, Y. 2020. Responses of rhizosphere and bulk substrate microbiome to wastewater-borne sulfonamides in constructed wetlands with different plant species. Sci Total Environ, 706, 135955.

Mandal, B., Das, S.C., Mandal, L.N.J.P., Soil. 1992. Effect of growth and subsequent decomposition of cyanobacteria on the transformation of phosphorus in submerged soils. 143(2), 289-297.

Mathon, B., Coquery, M., Miege, C., Vandycke, A., Choubert, J.M. 2019. Influence of water depth and season on the photodegradation of micropollutants in a free-water surface constructed wetland receiving treated wastewater. Chemosphere, 235, 260-270.

Milobedzka, A., Muszynski, A. 2015. Population dynamics of filamentous bacteria identified in Polish full-scale wastewater treatment plants with nutrients removal. Water Sci Technol, 71(5), 67584.

Mun, H., Townley, H.E. 2021. Nanoencapsulation of Plant Volatile Organic Compounds to Improve Their Biological Activities. Planta Med, 87(3), 236-251.

Navarro-Ortega, A., Tauler, R., Lacorte, S., Barceló, D. 2010. Occurrence and transport of PAHs, pesticides and alkylphenols in sediment samples along the Ebro River Basin. Journal of Hydrology, 383(1-2), 5-17.

Navel, S., Mermillod-Blondin, F., Montuelle, B., Chauvet, E., Marmonier, P. 2012. Sedimentary context controls the influence of ecosystem engineering by bioturbators on microbial processes in river sediments. Oikos, 121(7), 1134-1144. 
Nilsson, C., Polvi, L.E., Gardeström, J., Hasselquist, E.M., Lind, L., Sarneel, J.M. 2015. Riparian and in-stream restoration of boreal streams and rivers: success or failure. Ecohydrology, 8(5), 753764.

Nubel U., Bateson M. M., Vandieken V., Wieland A., Kuhl K., Ward D. M., 2002. Microscopic Examination of Distribution and Phenotypic Properties of Phylogenetically Diverse Chloroflexaceae-Related Bacteria in Hot Spring Microbial Mats[J]. Applied \& Environmental Microbiology, 68(9):4593-603.

Özgencil, İ.K., Beklioğlu, M., Özkan, K., Tavşanoğlu, Ç., Fattorini, N., 2020. Changes in functional composition and diversity of waterbirds: The roles of water level and submerged macrophytes. Freshwater Biology, 65(11), 1-13.

Pan, B., Yuan, J., Zhang, X., Wang, Z., Chen, J., Lu, J., Yang, W., Li, Z., Zhao, N., Xu, M. 2016. A review of ecological restoration techniques in fluvial rivers. International Journal of Sediment Research, 31(2), 110-119.

Frankenbach, S., SeroDio, J., 2017. One pulse, one light curve: Fast characterization of the light response of microphytobenthos biofilms using chlorophyll fluorescence. Limnology and Oceanography: Methods.

Rugner, H., Schwientek, M., Milacic, R., Zuliani, T., Vidmar, J., Paunovic, M., Laschou, S., Kalogianni, E., Skoulikidis, N.T., Diamantini, E., Majone, B., Bellin, A., Chiogna, G., Martinez, E., Lopez de Alda, M., Diaz-Cruz, M.S., Grathwohl, P. 2019. Particle bound pollutants in rivers: Results from suspended sediment sampling in Globaqua River Basins. Sci Total Environ, 647, 645652.

San Bautista, A., Calatayud, A., Nebauer, S.G., Pascual, B., Maroto, J.V., López-Galarza, S. 2011. 
Effects of simple and double grafting melon plants on mineral absorption, photosynthesis, biomass and yield. Scientia Horticulturae, 130(3), 575-580.

Song, C., Liu, X., Song, Y., Liu, R., Gao, H., Han, L., Peng, J. 2017. Key blackening and stinking pollutants in Dongsha River of Beijing: Spatial distribution and source identification. Journal of Environmental Management, 200, 335-346.

Su, T.-M., Yang, S.-C., Shih, S.-S., Lee, H.-Y. 2009. Optimal design for hydraulic efficiency performance of free-water-surface constructed wetlands. Ecological Engineering, 35(8), 12001207.

Takahashi, S., Badger, M.R. 2011. Photoprotection in plants: a new light on photosystem II damage. Trends Plant Sci, 16(1), 53-60.

Tang, S., Liao, Y., Xu, Y., Dang, Z., Zhu, X., Ji, G. 2020. Microbial coupling mechanisms of nitrogen removal in constructed wetlands: A review. Bioresour Technol, 314, 123759.

Wang, H., Wang, J., Bo, G., Wu, S., Luo, L. 2020. Degradation of pollutants in polluted river water using Ti/IrO2-Ta2O5 coating electrode and evaluation of electrode characteristics. Journal of Cleaner Production, 273.

Wang, J., Gu, Y., Wang, H., Li, Z. 2021. Investigation on the treatment effect of slope wetland on pollutants under different hydraulic retention times. Environ Sci Pollut Res Int, 28(8), 91079119.

Wang, Q., Xie, H., Ngo, H.H., Guo, W., Zhang, J., Liu, C., Liang, S., Hu, Z., Yang, Z., Zhao, C. 2016. Microbial abundance and community in subsurface flow constructed wetland microcosms: role of plant presence. Environ Sci Pollut Res Int, 23(5), 4036-45.

Wang, X., Tian, Y., Liu, H., Zhao, X., Peng, S. 2019. Optimizing the performance of organics and 

nutrient removal in constructed wetland-microbial fuel cell systems. Sci Total Environ, 653, 860-871.

Wang, X., Wang, S., Peng, G., S. w. katz, D., Ling, H. 2017. Ecological restoration for river ecosystems: comparing the huangpu river in shanghai and the hudson river in new york. Ecosystem Health and Sustainability, 1(7), 1-14.

White, A.J., Critchley, C.J.P.R. 1999. Rapid light curves: A new fluorescence method to assess the state of the photosynthetic apparatus. 59(1), 63-72.

Wolinska, A., FraC, M., Oszust, K., Szafranek-Nakonieczna, A., Zielenkiewicz, U., Stępniewska, Z., 2017. Microbial biodiversity of meadows under different modes of land use: catabolic and genetic fingerprinting. World Journal of Microbiology \& Biotechnology, 33(8), 154-169.

Xiong, C., Tam, N.F., Dai, Y., Zhang, X., Li, R., Zheng, Y., Wang, L., Yang, Y. 2020. Enhanced performance of pilot-scale hybrid constructed wetlands with $\mathrm{A} / \mathrm{O}$ reactor in raw domestic sewage treatment. J Environ Manage, 258, 110026.

Yaghoubian, Y., Siadat, S.A., Moradi Telavat, M.R., Pirdashti, H. 2016. Quantify the response of purslane plant growth, photosynthesis pigments and photosystem II photochemistry to cadmium concentration gradients in the soil. Russian Journal of Plant Physiology, 63(1), 7784.

Yang, J., Li, Q., An, Y., Zhang, M., Du, J., Chen, C., Zhao, R., Zhao, D., An, S. 2020. The improvement of pollutant removal efficiency in saturated vertical flow constructed wetlands by tubifex tubifex. Bioresour Technol, 318, 124202.

Yuan, K., Chen, B., Qing, Q., Zou, S., Wang, X., Luan, T. 2017. Polycyclic aromatic hydrocarbons (PAHs) enrich their degrading genera and genes in human-impacted aquatic environments. 
721

Zhang, C.B., Wang, J., Liu, W.L., Zhu, S.X., Liu, D., Chang, S.X., Chang, J., Ge, Y. 2010. Effects of plant diversity on nutrient retention and enzyme activities in a full-scale constructed wetland. Bioresour Technol, 101(6), 1686-92.

Zhang, L., Liu, H., Peng, Y., Zhang, Y., Sun, Q. 2020a. Characteristics and significance of dissolved organic matter in river sediments of extremely water-deficient basins: A Beiyun River case study. Journal of Cleaner Production, 277.

Zhang, P., Zhang, Z., Li, B., Zhang, H., Hu, J., Zhao, J. 2020b. Photosynthetic rate prediction model of newborn leaves verified by core fluorescence parameters. Sci Rep, 10(1), 3013.

Zheng, Y., Yang, D., Dzakpasu, M., Yang, Q., Liu, Y., Zhang, H., Zhang, L., Wang, X.C., Zhao, Y. 2020. Effects of plants competition on critical bacteria selection and pollutants dynamics in a longterm polyculture constructed wetland. Bioresource Technology, 316.

Zhang, X., Qin, H., Wang, H., Wan, A., Liu, G., 2018. Effects of water level fluctuations on root architectural and morphological traits of plants in lakeshore areas of three subtropical floodplain lakes in China. Environ Sci Pollut Res Int, 25(34), 34583-34594.

Ziv-El M., Delgado A. G., Yao Y., Kang D.W., Nelson K. G., Halden R.U., Krajmalnik-Brown R., 2011. Development and characterization of DehaloR^2, a novel anaerobic microbial consortium performing rapid dechlorination of TCE to ethene[J]. Applied Microbiology \& Biotechnology, 92(5):1063-1071.

Zou, L., Luo, Y., Hooper, M., Hu, E. 2006. Removal of VOCs by photocatalysis process using adsorption enhanced $\mathrm{TiO} 2-\mathrm{SiO} 2$ catalyst. Chemical Engineering and Processing: Process Intensification, 45(11), 959-964. 
